\title{
Exploring Hotel Management Innovation
}

\author{
Chieh-Heng Ko \\ Department of Hospitality Management, College of Tourism and Hospitality, Da-Yeh University, Taiwan \\ Email: chko@mail.dyu.edu.tw
}

How to cite this paper: Ko, C.-H. (2018) Exploring Hotel Management Innovation. Open Access Library Journal, 5: e4997. https://doi.org/10.4236/oalib.1104997

Received: October 23, 2018

Accepted: December 9, 2018

Published: December 12, 2018

Copyright $\odot 2018$ by author and Open Access Library Inc.

This work is licensed under the Creative Commons Attribution International License (CC BY 4.0).

http://creativecommons.org/licenses/by/4.0/

\begin{abstract}
The study of management innovation has gained relevance in recent years, but there is a lack of empirical research analyzing the factors that favor it. This article contemplates two types of antecedents of management innovation in the hospitality industry. In the internal context of the company, the influence of the employees' knowledge and skills is analyzed, as well as the company's capacity to integrate this knowledge. In the external setting, an evaluation is performed of the way relationships established with tourist industry agents and external change agents affect the development of management innovation. The data obtained from 27 firms operating hotel establishments in Taiwan show that both the internal resources and the relations with external change agents determine the introduction of management innovations. However, access to knowledge held by tourist industry agents does not influence management innovation.
\end{abstract}

\section{Subject Areas}

Economics, Marketing

\section{Keywords}

Management Innovation, Human Capital, Integration Capability, Social

Relationships

\section{Introduction}

Although it involves risks and its success is not guaranteed, innovation is considered a requirement for adapting to a changing environment [1]. Due to strong competition, numerous technological advancements and changes in consumers' tastes, firms' survival depends on their capacity to develop or adopt innovations [2]. For years, studies on innovation have focused on its technological aspects. However, the field of innovation deals with other aspects, such as business model innovation, service innovation or management innovation [3]. Management 
innovation is a relatively recent term, although the concept has been discussed previously using similar terms such as organizational or administrative innovation. Innovation in management principles and processes has received growing academic interest, and in recent years studies have analyzed it together with technological innovation [4] and independently. The article by Birkinshaw, Hamel, and Mol [5] provided an interesting discussion on management innovation, which led to other papers on this topic [6] [7] that will probably provide the basis for many future research opportunities.

Management innovation explains an important part of a company's innovative performance. It can create sustainable competitive advantages that lead to economic success, and it can redefine an industry through the propagation of new ideas [7]. These innovations in management practices and processes are especially relevant to services activities. However, because the study of management innovation as a relevant variable has only emerged in recent years, little is known about its determining factors, and studies in the hospitality sector are especially scarce. Therefore, research studies should be carried out to reach a better understanding of management innovation.

Birkinshaw et al. [8] identify four perspectives on management innovation: 1) institution, which is related to the socioeconomic conditions in which management innovation takes place; 2) fashion, which focuses on the interaction between those who supply ideas and those who use them; 3) culture, which refers to the way an organization reacts to the introduction of new management ideas and practices; and 4) rationality, which focuses on improvements in organizational effectiveness provided by management innovation. The present study aims to contribute to the emerging scholarly discourse by combining the rational and fashion perspectives to analyze antecedents of management innovation in hotel firms. Specifically, it analyzes the role played by two internal resources, human capital and integration capability, as well as the effect of managers' relations with external agents as promoters of management innovation. Therefore, the study makes it possible to advance the knowledge in the underdeveloped literature on management innovation by empirically testing the role played by internal and external factors to the organization.

\section{Literature Review}

\subsection{Management Innovation}

The literature presents two perspectives, both considered valid, of the degree of novelty in management innovations [8]: "new to the state of the art", which means there is no known precedent; and new to the adopting organization. Both perspectives view innovation as a significant improvement in past management activities and competences designed to favor a closer alignment with the competitive environment [9]. Management innovation, therefore, refers to the generation or adoption of management processes, practices, structures or techniques that are new to the company and affect its performance in terms of inno- 
vation, productivity and competitiveness [8]. Therefore, it involves: "changes in the way management work is done, involving a departure from traditional processes (i.e., what managers do as part of their jobs); in practices (i.e., the routines that turn ideas into actionable tools); in structure (i.e., the way in which responsibility is allocated); and in techniques (i.e., the procedures used to accomplish a specific task or goal)". The literature shows a consensus that these changes can constitute one of the main sources of competitive advantage for firms, given that they are context-specific, complex, ambiguous and hard to replicate [10].

Management innovation has characteristics that distinguish it from product innovations. On the one hand, management innovations are basically introduced to improve the efficiency of the organization's internal administrative processes, while the innovation of goods or services tries to satisfy external demands [11]. On the other hand, the non-technological nature of management innovation means that, in its development and adoption, the firm's managers play a more important role than technicians or researchers do [12].

Scant empirical research has analyzed the variables that foster management innovation. The first studies carried out in this field were more focused on structural aspects of the organization. Ac-cording to Daft [13], a mechanistic structure is appropriate for administrative innovations. Damanpour [14] finds that administrative intensity and organizational size positively influence administrative innovations. A meta-analysis carried out by Kimberly and Evanisko [15] shows that vertical and functional differentiation is positively associated with administrative innovations. More recent studies have incorporated new variables as determinants of management innovation. Mol and Birkinshaw [16] show that management innovation depends on both the internal context of the company and the external search for new knowledge. According to Orfila-Sintes and Mattsson [17], firm size, the use of assets, services in addition to accommodation, and employees' qualifications positively influence management innovation. Vaccaro et al. [7] find that transformational and transactional leadership behaviors positively contribute to management innovation. The study by Hecker and Ganter [12] shows that rapid technological changes favor the firm's propensity to adopt management innovation. Cerne et al. [6] find that knowledge exchange is positively related to management innovation.

This article adopts, on the one hand, a rational perspective to examine how two internal resources favor the introduction of new management practices, processes and structures designed to enhance firm performance. The paper proposes, first, that the employees' knowledge, abilities and skills, as well the organization's capacity to integrate this knowledge, favor the development of management innovation. However, although companies can undertake management innovation processes on their own, they find it valuable to selectively use outsiders, who represent a source of ideas for different settings [5]. Therefore, on the other hand, the article proposes that access to external knowledge 
influences management innovation from a fashion perspective; that is, managers use new management ideas presented by "fashion setters" [18]. Specifically, the study proposes that new knowledge is accessed through two types of relationships that managers can have with external agents, and it suggests that these relationships influence management innovation in different ways. The first proposal is that managers' relationships with tourist industry agents does not influence the development of management innovation because the idiosyncratic nature of management practices and processes hinders the transfer of knowledge from one organization to another [16]. The second proposal is that managers' relationships with external change agents favor the introduction of management innovation, given that the literature considers these agents to be fundamental in initiating and driving the process [5].

\subsection{Human Capital and Management Innovation}

The literature emphasizes the role of human capital as an antecedent of knowledge creation and innovation. A high level of knowledge, abilities and skills favors better use of information, rapid learning, and the effective application of what was learnt, all of which contribute positively to innovation [19]. Similarly, employees with high levels of knowledge will probably be more receptive to new ideas and changes [20]. Furthermore, high levels of human capital are associated with more tacit knowledge, familiarity and efficiency, which reduce the perception of risk and favor change [21]. In addition, when employees have high levels of knowledge, the combination and exchange of this knowledge will be more productive, creating more knowledge [22]. Moreover, as new knowledge is built on the stock of existing knowledge, a prior knowledge base favors the comprehension and absorption of the knowledge to which one is exposed. Thus, organizations with better human capital can improve their capacity to handle the complex processes that accompany change and create new knowledge [22].

Specifically in the area of management innovation, Birkinshaw et al. [8] highlight the key role of human agency in the development of new management practices, processes and structures. Qualified employees are an important attribute of companies and represent one of their key management innovation resources [10]. Individuals play a fundamental role in identifying new tendencies and supporting initiatives related to management changes [7]. Wu [23] points out that highly qualified employees increase the capacity to develop management innovation because they have strong analytical abilities and a broad knowledge base. Along the same lines, Mol and Birkinshaw [16] consider that well-educated employees are capable of perceiving questions beyond their specific jobs, increasing the possibilities of introducing new management practices. Orfila-Sintes and Mattsson [17] suggest that knowledge resources are more important for management innovations than for any other type of innovation. They find that management innovation increases when companies have more employees with university degrees. Moreover, the study by Kimberly and Eva- 
nisko [15] shows that the educational level of the administrator positively determines the introduction of management innovations. These arguments lead to the following hypothesis.

Hypothesis H1. The firm's human capital positively affects the introduction of management innovations.

\subsection{Integration Capability and Management Innovation}

Different types of employees have different types of knowledge related to the organization, which makes it possible for individuals to contribute proposals related to their specific abilities that fit the organization's objectives [24]. These different types of knowledge can become a valuable resource when the company is able to integrate them. Integration capability is defined as the ability to combine individual knowledge, and it consists of three basic routines [25]: 1) contribution, which relates to collecting and combining individual inputs; 2) representation, which makes it possible to build a shared understanding; and 3) Interrelation, which relates to a new logic of collective interaction. Integration capability favors the trans-formation of diverse knowledge into a new form of knowledge that is both integrated and novel, fostering the innovative activity [26].

Management innovation is the result of the way different individuals think, interpret, act or interact. Therefore, if management innovation must be analyzed as the product of collective action, and not as the will of specific individuals, it will be necessary to integrate the knowledge of different individuals within the organization. In other words, the organization must be capable of effectively managing and integrating the employees' knowledge, which requires knowing where the different types of abilities and skills are located. In this way, managers can obtain precise information that helps them to make well-informed decisions about what solutions can be adopted, allowing them to be more successful in the search for management innovations [27]. In summary, given that management innovation is a supra-individual process, the organization will obtain advantages if it can integrate individual knowledge into a collective system. Based on these arguments, this article formulates the following hypothesis.

Hypothesis H2. The organization's capacity to integrate the employees' knowledge positively affects the introduction of management innovations.

\subsection{Managers' External Relationships and Management Innovation}

The role of external social networks as determinants of innovation has repeatedly been emphasized in the literature [28]. Knowledge situated outside the organizational limits provides companies with varied and numerous sources of knowledge, whose combination can give rise to true innovations [29]. This paper analyses how social relationships between members of firms' management teams and external agents influence the adoption of management innovations. Vaccaro 
et al. [7] state that managers have the capacity to significantly influence the development of management innovations, due to their prominent role within the organization.

Different research studies show that acquiring knowledge from outside sources is a critical determinant of management innovation [10]. Specifically, Mol and Birkinshaw [16] point out that building knowledge-based external relationships positively influences the ability to successfully introduce new management practices. These authors argue that at least part of this outside knowledge must come from specific organizations that have knowledge about management practices. Mol and Birkinshaw [16] analyzed one category of sources, the so-called market sources, which include suppliers, clients or customers, competitors, consultants, and commercial laboratories/R \& D enterprises. This paper addresses external knowledge sources by distinguishing between managers' relationships with: 1) external change agents, which include consultants and academic researchers; and 2) tourist industry agents, which include clients, suppliers and companies in the sector.

Management innovation has been related to agents outside the company who have appropriate abilities and novel ideas, and whose external position allows them to overcome organizational inertia and challenge the existing norms [30]. Based on this argument, this study adopts a fashion perspective that "focuses on how management innovations emerge through the dynamic interplay between managers who use new management ideas and 'fashion setters' who put forward those ideas" [5], and it proposes that managers' relationships with external change agents favor management innovation. Volberda et al. [10] argue that the search for management innovation is influenced by external change agents because new practices, processes or structures are often modelled by third parties, such as consultants and academic researchers, who initiate and lead the process. According to Birkinshaw and Mol [5], external change agents focus more on ideas than on practical questions. However, together with the organization's man-agers, they are able to reduce the gap between the concept and implementation of management innovations.

On the other hand, the literature highlights that the develop-ment of management innovation is a complex process and specific to the company. Its idiosyncratic and intangible nature makes it difficult to imitate [6], replicate [10] or transfer from one organization to another [16]. Therefore, management innovations are generally unique to each adopting firm [31] and have strong roots in the organizational and social context of the company that implements them [12]. Likewise, the knowledge involved in these types of innovations has an important tacit component, which can interfere with its comprehension and assimilation by external observers [12]. Based on these arguments, this study proposes that the top management team's relationships with external change agents are more important than their relationships with tourist industry agents in the introduction of management innovations. Therefore, although external relationships in 
general provide access to information, knowledge and ideas that can favor management innovation activities, this paper proposes that relationships with external change agents play a more determinant role than relationships with tourism industry agents.

Hypothesis H3a. The top management team's social relationships with external change agents positively affect the introduction of management innovations.

Hypothesis H3b. The top management team's social relationships with tourist industry agents positively affect the introduction of management innovations.

Hypothesis H3c. Social relationships with external change agents affect the introduction of management innovations more than social relationships with tourist industry agents.

\section{Methodology}

Relevant data was collected by means of questionnaire survey specifically developed for the hotel managers. This research sample consisted of managers from 27 hotels in Taiwan. A total of 320 questionnaires were distributed, and 253 (79.1\%) questionnaires were received due to large portions of missing values. Finally, 239 (74.7\%) questionnaires were analyzed in this study.

To measure all of the variables, 7-point Likert-type scales were used. Human capital was measured by adapting the scale used by Subramaniam and Youndt [32]. To measure integration capacity, the scale proposed by Pavlou and El Sawy [25] was used. Management innovation was measured based on what was established in the Oslo Manual [33]. Although the Oslo Manual uses the term organizational innovations, the concept can be considered equivalent to management innovation [12]. For these variables measured with scales, the individuals surveyed were asked to indicate their degree of agreement with the items on the questionnaire, using a response range from $1=$ strongly disagree to $7=$ strongly agree.

The managers' external social relationships were measured as an additive index. To evaluate the social relationships with industry agents, the interviewees were asked if any members of the top management team maintained work-related personal contact with: 1) end users; 2) intermediate customers (travel agencies, tour operators, etc.); 3) other hotel chains or establishments; 4) other companies in the sector (transport, leisure, restaurants, etc.); or 5) suppliers of equipment, software, material, etc. Relationships with external change agents were measured by asking the managers if any members of the top management team maintained work-related personal contact with: 1) consultants or experts; 2) universities, agencies or research and innovation institutes. The response range was from $1=$ almost never to $7=$ almost always. Due to the difficulty of asking each of the top management members this question, in this study we adapted the questions to the perception of the manager who filled out the questionnaire. This methodology has been used previously by authors such as Houghton, Smith, and Hood [34]. 
This study statistically controlled the effect of firm size, measured through the logarithmic transformation of the number of employees. There is no consensus in the literature about the relationship between firm size and management innovation. Daft [13] finds that the firm size has no effect on the process of administrative innovation. $\mathrm{Wu}$ [23] suggests that the inertia that characterizes large companies can keep them from adopting new management practices because this implies facing more organizational challenges. According to Vaccaro [7], larger organizations, although they have a larger stock of resources, can lack the necessary flexibility to introduce management innovations. Like-wise, Vaccaro [7] argue that large organizations can find it more difficult to develop management innovation due to their greater complexity, bureaucratic formalization, and increased spatial separation. However, their study shows that the effect of transformational leadership on management innovation increases with organizational size. Kimberly and Evanisko [15] find that organizational size is positively associated with management innovations. Mol and Birkinshaw [16] state that large companies are more likely to introduce new management practices, given that they have more resources, including knowledge about management practices and human capital. Volberda et al. [10] point out that large companies have been shown to have more ingenuity than small ones, but their need to introduce management innovations is also greater. Specifically in the hospitality industry, Orfila-Sintes and Mattsson [17] find that firm size is positively related to management innovation in hotels. Consequently, we expect to find a positive relationship between firm size and management innovation.

\section{Results}

Unlike scales, additive indexes do not have to be highly correlated with each other, so that Cronbach's alpha is not an appropriate measure, and factorial analysis is not an appropriate procedure. Therefore, the evaluation of the psychometric properties was carried out on the variables measured with scales. Exploratory factorial analysis (EFA), in a phase prior to the confirmatory factorial analysis, showed the existence of only one dimension in the scales used. After per-forming the EFA, the measurement model was estimated by means of confirmatory factorial analysis (CFA) to test the goodness of fit of each scale. The scales showed a good level of fit and acceptable psychometric properties. Their reliability was evaluated based on the Cronbach's alpha co-efficient and by calculating the composite reliability and variance extracted. The Cronbach's alpha values were above 0.87 . The composite reliability in all the constructs was above 0.91 . Moreover, the average variance extracted (AVE) was above 0.72 on all the scales, surpassing the recommended threshold of 0.50 . In the same way, the convergent validity of the scales was contrasted, given that all the standardized estimators of the regression weights of the latent variable on the indicators are statistically significant, positive, and greater than 0.77 . Finally, the discriminant validity was evaluated by testing whether the AVE of each construct was greater 
than the squared correlation between two constructs. To simplify the procedure, the square root of the variance extracted of each construct was calculated (Table 1). As can be observed, all the constructs have the property of discriminant validity.

To contrast the hypotheses, multiple lineal regression analyses were performed. One of the assumptions that must be met to guarantee the validity of the lineal regression model is the independence of the error terms. The DurbineWatson (DeW) statistic provides information about the degree of independence existing between the residuals. If the value of the statistic is near 2, it can be assumed that there is independence. Likewise, the Variance Inflation Factor (VIF) was examined for each independent variable in order to evaluate the risk of multicollinearity. The VIF values ranged from 1.200 to 2.262 , indicating that multicollinearity is not a problem. Four models were specified for the regression analysis (Table 2). Model 1 only includes the control variable, and it is significant at $\mathrm{p}<0.001$. Model 2 also includes the effect of the variables that represent the two internal resources analyzed, human capital and integrating capability. Model 2 is significant at the $\mathrm{p}<0.001$ level and explains an additional $36 \%$ of the variance, compared to Model 1 . Model 3 includes managers' external relationships, both with tourist industry agents and with external change agents, in addition to the control variable. Model 3 is also significant at the $p<0.001$ level and explains $32 \%$ of the variance in management innovation. The results for Model 3 indicate that relationships with external change agents positively and significantly affect the introduction of management innovation, but relations with tourist industry agents do not show a significant relationship with management innovation. Finally, Model 4 includes all the variables that have a significant effect on management innovation, in addition to the control variable. As Table 2 shows, Model 4 is significant at the $\mathrm{p}<0.001$ level and explains $50 \%$ of the variance in management innovation.

The results show that the two internal resources analyzed, human capital and

Table 1. Measurement information: mean, standard deviation, correlations ( $\mathrm{n}=109)$.

\begin{tabular}{|c|c|c|c|c|c|c|c|c|}
\hline & Mean & $\begin{array}{l}\text { Stand. } \\
\text { Deviat. }\end{array}$ & $(1)$ & (2) & (3) & $(4)$ & (5) & (6) \\
\hline (1) Human capital & 3.96 & 1.11 & $(0.869)$ & & & & & \\
\hline (2) Integration capability & 4.07 & 0.99 & $0.660^{* *}$ & $(0.849)$ & & & & \\
\hline $\begin{array}{l}\text { (3) Social relationships with } \\
\text { industry agents }\end{array}$ & 5.31 & 1.10 & $0.418^{* *}$ & $0.439^{\star *}$ & n.a. & & & \\
\hline $\begin{array}{l}\text { (4) Social relationships with } \\
\text { external change agents }\end{array}$ & 4.68 & 1.53 & $0.499^{* *}$ & $0.487^{* *}$ & $0.698^{\star *}$ & n.a & & \\
\hline (5) Management innovation & 3.59 & 1.22 & $0.634^{\star *}$ & $0.620^{\star *}$ & $0.381^{\star *}$ & $0.525^{\star \star}$ & $(0.851)$ & \\
\hline (6) Firm size & 603.5 & 1992.5 & $0.358^{* *}$ & $0.241^{*}$ & 0.040 & $0.218^{* *}$ & $0.384^{\star *}$ & n.a \\
\hline
\end{tabular}

${ }^{*}$ The correlation is significant at 0.01 level (bilateral). ${ }^{*}$ The correlation is significant at 0.05 level (bilateral). The elements on the diagonal (values between parentheses) correspond to the square root of the AVE of the construct; n.a: not applicable. 
Table 2. Results of hierarchical regression analyses: management innovation.

\begin{tabular}{|c|c|c|c|c|c|c|c|c|c|}
\hline & \multirow[t]{2}{*}{ VIF } & \multicolumn{2}{|c|}{ Model 1} & \multicolumn{2}{|c|}{ Model 2} & \multicolumn{2}{|c|}{ Model 3} & \multicolumn{2}{|c|}{ Model 4} \\
\hline & & Beta & $t$-value & Beta & $t$-value & Beta & $t$-value & Beta & $t$-value \\
\hline Firm size & 1.200 & 0.348 & $3.840^{* * *}$ & 0.137 & 1.834 & 0.255 & $3.092^{\star *}$ & 0.128 & 1.757 \\
\hline Human capital & 2.058 & & & 0.350 & & & & 0.287 & $2.958^{\star *}$ \\
\hline Integration capability & 1.910 & & & 0.356 & $3.623^{* * *}$ & & & 0.297 & $3.191^{\star *}$ \\
\hline $\begin{array}{l}\text { Social relationships with } \\
\text { industry agents }\end{array}$ & 2.089 & & & & $3.833^{* * *}$ & 0.083 & 0.743 & & \\
\hline $\begin{array}{l}\text { Social relationships with } \\
\text { external change agents }\end{array}$ & 2.262 & & & & & 0.412 & $3.576^{* *}$ & 0.210 & $2.596^{*}$ \\
\hline $\mathrm{R}^{2}$ & & 0.121 & & 0.490 & & 0.337 & & 0.521 & \\
\hline Adjusted $\mathrm{R}^{2}$ & & 0.113 & & 0.475 & & 0.318 & & 0.502 & \\
\hline F change & & 14.744 & & 33.603 & & 17.776 & & 28.265 & \\
\hline $\mathrm{D}-\mathrm{W}$ & & 2.226 & & 2.356 & & 2.086 & & 2.297 & \\
\hline
\end{tabular}

$\mathrm{n}=109 ;{ }^{* *} \mathrm{p}<0.001 ;{ }^{* *} \mathrm{p}<0.01 ;{ }^{*} \mathrm{p}<0.05$.

integrating capability, positively and significantly influence management innovation, supporting $\mathrm{H} 1$ and $\mathrm{H} 2$. The results also support $\mathrm{H} 3 \mathrm{a}$, which proposes a positive relationship between managers' social relations with external change agents and management innovation. However, there is no empirical evidence for the hypothesis that social relationships with tourism industry agents have a positive effect on management innovation; therefore, H3b is not supported. Moreover, given that only the social relationships with external change agents influence management innovation, $\mathrm{H} 3 \mathrm{c}$ is not supported either. Table 2 shows that firm size is positively related to management innovation (Model 1 and Model 3), although this relationship is no longer significant when human capital and integration capability are included (Model 2). These results suggest that the relationship between firm size and management innovation is mediated by some of these internal resources analyzed. In order to evaluate this mediator effect, additional regression analyses were performed. Following Baron and Kenny's procedure [35], first it was observed that firm size (Model 1) and human capital (Model 2) are positively related to management innovation. Second, the effect of firm size on human capital was examined. The results indicate that this relationship is positive and significant $(b=0.358 ; p=0.001)$. Finally, the joint effect of firm size and human capital on management innovation was examined. The coefficients show that the relationship between human capital and management innovation is positive and significant $(b=0.584 ; p<0.001)$, but the inclusion of the human capital variable in the model makes the relationship between company size and management innovation become non-significant $(b=0.139 ; p>$ 0.05). Therefore, human capital plays a mediator role in the relationship between firm size and management innovation. The same procedure was followed to evaluate the possible mediator effect of integration capability. The results show that, when including firm size and integration capability together in the model, 
the effect of firm size on management innovation continues to be significant ( $b$ $=0.211 ; \mathrm{p}<0.01)$, indicating that integration capability does not mediate in this relationship.

\section{Discussion and Conclusions}

This article combines two theoretical perspectives, rationality and fashion, to analyze the antecedents of management innovation in firms in the hotel industry. Based on a rational approach, the study has showed that certain internal and external factors favor management innovations and, therefore, contribute to improving organizational efficacy. From a fashion perspective, the study has empirically showed the important role played by providers of management ideas, as they help to identify and implement new practices, processes or structures. The theoretical study by Birkinshaw et al. [5] points to two groups of individuals who shape the process of management innovation: internal change agents or employees, and external change agents or consultants, academic researchers, and gurus. The present empirical study shows that both resources, internal and external, are factors that explain the introduction of new management practices and processes.

Specifically, the results suggest that employees with high levels of knowledge, abilities and skills play a relevant role in the introduction of management innovations. Likewise, the firm's capacity to integrate the knowledge dispersed throughout the organization positively influences the achievement of management innovations. These results complement the proposals by McCabe [36], who states that, even though management innovations are located in a context of power and inequality, they constitute a process in which managers and workers can participate on equal terms.

Improving the capacity for innovation can also be achieved by relying on agents outside the organization. In this sense, this study finds that the management team's relationships with tourist industry agents do not show a significant relationship with management innovation. The results suggest that the specific and idiosyncratic nature of management innovation hinders the transfer of knowledge from external organizations. Thus, managers will not be able to absorb this type of knowledge to implement their own management innovations. The study by Mol and Birkinshaw [16] finds that market sources provide new ideas that influence the introduction of new management practices in all sectors, except construction and utilities and other services. Their results, together with the results from the present study, suggest that additional studies should be carried out to evaluate: 1) the effects that the different types of external relationships can have on management innovation; and 2) the effects that external relation-ships can have on management innovation activities in companies from different economic sectors.

In addition, the data show that relationships with external change agents contribute significantly to the introduction of new management practices. External change agents have specific knowledge and prior experience related to manage- 
ment innovations, which means they have the capacity to help the organization to adopt new practices, processes and structures. These results are consistent with the theoretical proposals of Birkinshaw and Mol [8], who maintain that external change agents generally provide initial inspiration for management innovation, in addition to helping to shape and legitimize the process. Damanpour [37] distinguishes between generation (development) and adoption (use) of new ideas or practices. The results suggest that relationships with external change agents can foster the adoption of practices and processes that already exist in the industry but are a novelty for the adopting firm. On the other hand, the implementation of management innovations developed by the firm itself could be determined by the firm's internal resources, specifically human capital and integration capability. However, additional research is needed to test these relationships, given that this study only shows that these internal resources and the relations with external change agents are antecedents of management innovations. Finally, the study finds that human capital mediates the relationship between firm size and management innovations. Therefore, the disparate results shown by previous studies may be due to the fact that they did not take into account other organizational variables affecting this relationship.

\section{Implications}

This study makes a novel contribution to the hospitality literature because it is a pioneer study in examining internal and external factors together as determinants of management innovation in the hotel industry. The results show that employees' knowledge and the capacity to integrate this knowledge favor the introduction of management innovations. Likewise, they show that, in the sector analyzed, only the relationships that managers establish with external change agents affect the achievement of management innovations. The particular organizational characteristics of each firm make any management changes highly specific, which reduces the possibility of transferring them from one organization to another. Consequently, the study shows that the introduction of new management practices and processes is only fostered by the information and knowledge coming from external expert sources, that is, the knowledge provided by consultants or academic researchers. In addition, this study developed a scale to measure management innovation, based on what was established in the Oslo Manual [33], and this scale shows acceptable psychometric properties.

Regarding the practical implications, the study suggests that firms can be more successful in developing management innovations if they invest in human capital and establish systems that make it possible to integrate the knowledge of the different members of the organization. Moreover, relations with specialists, such as consultants or researchers, are a tool that management teams can use to promote new management practices, processes and structures.

\section{Conflicts of Interest}

The author declares no conflicts of interest regarding the publication of this paper. 


\section{References}

[1] Rhee, J., Park, T. and Lee, D.H. (2010) Drivers of Innovativeness and Performance for Innovative SMEs in South Korea: Mediation of Learning Orientation. Technovation, 30, 65-75. https://doi.org/10.1016/j.technovation.2009.04.008

[2] Damanpour, F., Walker, R.M. and Avellaneda, C.N. (2009) Combinative Effects of Innovation Types and Organizational Performance: A Longitudinal Study of Service Organizations. Journal of Management Studies, 46, 650-675. https://doi.org/10.1111/j.1467-6486.2008.00814.x

[3] Gallego, J., Rubalcaba, L. and Hipp, C. (2013) Services and Organisational Innovation: the Right Mix for Value Creation. Management Decision, 51, 1117-1134. https://doi.org/10.1108/MD-11-2012-0446

[4] Camison, C. and Villar-Lopez, A. (2014) Organizational Innovation as an Enabler of Technological Innovation Capabilities and Firm Performance. Journal of Business Research, 67, 2891-2902. https://doi.org/10.1016/j.jbusres.2012.06.004

[5] Birkinshaw, J., Hamel, G. and Mol, M.J. (2008) Management Innovation. Academy of Management Review, 33, 825-845. https://doi.org/10.5465/amr.2008.34421969

[6] Cerne, M., Jaklic, M. and Skerlavaj, M. (2013) Management Innovation in Focus: The Role of Knowledge Exchange, Organizational Size, and IT System Development and Utilization. European Management Review, 10, 153-166.

https://doi.org/10.1111/emre.12013

[7] Vaccaro, I.G., Jansen, J.J.P., Van Den Bosch, F.A.J. and Volberda, H.W. (2012) Management Innovation and Leadership: The Moderating Role of Organizational Size. Journal of Management Studies, 49, 28-51.

https://doi.org/10.1111/j.1467-6486.2010.00976.x

[8] Birkinshaw, J. and Mol, M. (2006) How Management Innovation Happens. MIT Sloan Management Review, 47, 81-88.

[9] Hollen, R.M.A., Van Den Bosch, F.A.J. and Volberda, H.W. (2013) The Role of Management Innovation in Enabling Technological Process Innovation: An Inter-Organizational Perspective. European Management Review, 10, 35-50. https://doi.org/10.1111/emre.12003

[10] Volberda, H.W., Van Den Bosch, F.A.J. and Heij, C.V. (2013) Management Innovation: Management as Fertile Ground for Innovation. European Management Review, 10, 1-15. https://doi.org/10.1111/emre.12007

[11] Walker, R.M., Damanpour, F. and Devece, C.A. (2010) Management Innovation and Organizational Performance: The Mediating Effect of Performance Management. Journal of Public Administration Research and Theory, 21, 367-386. https://doi.org/10.1093/jopart/muq043

[12] Hecker, A. and Ganter, A. (2013) The Influence of Product Market Competition on Technological and Management Innovation: Firm-Level Evidence from a Large-Scale Survey. European Management Review, 10, 17-33. https://doi.org/10.1111/emre.12005

[13] Daft, R.L. (1978) A Dualcore Model of Organizational Innovation. Academy of Management Journal, 21, 193-210.

[14] Damanpour, F. (1987) The Adoption of Technological, Administrative, and Ancillary Innovations: Impact of Organizational Factors. Journal of Management, 13, 675-688. https://doi.org/10.1177/014920638701300408

[15] Kimberly, J.R. and Evanisko, M.J. (1981) Organizational Innovation: The Influence of Individual, Organizational, and Contextual Factors on Hospital Adoption of 
Technological and Administrative Innovations. Academy of Management Journal, 24, 689-713.

[16] Mol, M.J. and Birkinshaw, J. (2009) The Sources of Management Innovation: When Firms Introduce New Management Practices. Journal of Business Research, 62, 1269-1280. https://doi.org/10.1016/j.jbusres.2009.01.001

[17] Orfila-Sintes, F. and Mattsson, J. (2009) Innovation Behavior in the Hotel Industry. Omega, 37, 380-394. https://doi.org/10.1016/j.omega.2007.04.002

[18] D’Amato, A. and Roome, N. (2009) Leadership of Organizational Change. Toward an Integrated Model of Leadership for Corporate Responsibility and Sustainable Development: A Process Model of Corporate Responsibility beyond Management Innovation. Corporate Governance, 9, 421-434. https://doi.org/10.1108/14720700910984972

[19] Lopez-Cabrales, A. and Valle, R. (2008) Capital humano, practicas de gestion empresarial: Estan relacionadas? Revista Europea de Direccion y Economía de la Empresa, 17, 155-178.

[20] Boeker, W. (1997) Executive Migration and Strategic Change: The Effect of Top Manager Movement on Product Market Entry. Administrative Science Quarterly, 42, 213-236. https://doi.org/10.2307/2393919

[21] Bruns, V., Holland, V., Shepherd, D.A. and Wiklund, J. (2008) The Role of Human Capital in Loan Officers' Decision Policies. Entrepreneurship Theory and Practice, 32, 485-506. https://doi.org/10.1111/j.1540-6520.2008.00237.x

[22] Smith, K.G., Collins, C.J. and Clark, K.D. (2005) Existing Knowledge, Creation Capability and the Rate of New Product Introduction in High-Technology Firms. Academy Management Journal, 48, 346-357. https://doi.org/10.5465/amj.2005.16928421

[23] Wu, L.-Y. (2010) Which Companies Should Implement Management Innovation? A Commentary Essay. Journal of Business Research, 63, 321-323. https://doi.org/10.1016/j.jbusres.2009.04.018

[24] Avlonitis, G., Kouremenos, A. and Tzokas, N. (1994) Assessing the Innovativeness of Organizations and Its Antecedents: Project Innovstrat. European Journal of Marketing, 28, 5-28. https://doi.org/10.1108/03090569410075812

[25] Pavlou, P.A. and El Sawy, O.A. (2011) Understanding the Elusive Black Box of Dynamic Capabilities. Decision Sciences, 42, 239-273. https://doi.org/10.1111/j.1540-5915.2010.00287.x

[26] Salazar, M.R., Lant, T.K., Fiore, S.M. and Salas, E. (2012) Facilitating Innovation in Diverse Science Teams through Integrative Capacity. Small Group Research, 43, 527-558. https://doi.org/10.1177/1046496412453622

[27] Cerne, M., Jaklic, M. and Skerlavaj, M. (2013) Management Innovation in Focus: The Role of Knowledge Exchange, Organizational Size, and IT System Development and Utilization. European Management Review, 10, 153-166. https://doi.org/10.1111/emre.12013

[28] Hjalager, A.M. (2010) A Review of Innovation Research in Tourism. Tourism Management, 31, 1-12. https://doi.org/10.1016/j.tourman.2009.08.012

[29] Miller, D.J., Fern, M.J. and Cardinal, L.B. (2007) The Use of Knowledge for Technological Innovation within Diversified Firms. Academy of Management Journal, 50, 308-326. https://doi.org/10.5465/amj.2007.24634437

[30] Wright, C., Sturdy, A. and Wylie, N. (2012) Management Innovation through Standardization: Consultants as Standardizers of Organizational Practice. Research 
Policy, 41, 652-662. https://doi.org/10.1016/j.respol.2011.12.004

[31] Damanpour, F. and Gopalakrishnan, S. (2001) The Dynamics of the Adoption of Product and Process Innovations in Organizations. Journal of Management Studies, 38, 45-65. https://doi.org/10.1111/1467-6486.00227

[32] Subramaniam, M. and Youndt, M.A. (2005) The Influence of Intellectual Capital on the Types of Innovative Capabilities. Academy of Management Journal, 48, 450-463. https://doi.org/10.5465/amj.2005.17407911

[33] OECD/Eurostat (2005) Guidelines for Collecting and Interpreting Innovation Data. http://www.oecd.org/science/inno/2367614.pdf

[34] Houghton, S.M., Smith, A.D. and Hood, J.N. (2009) The Influence of Social Capital on Strategic Choice: An Examination of the Effects of External and Internal Network Relationships on Strategic Complexity. Journal of Business Research, 62, 1255-1261. https://doi.org/10.1016/j.jbusres.2009.01.002

[35] Baron, R.M. and Kenny, D.A. (1986) The Moderator-Mediator Variable Distinction in Social Psychological Research: Conceptual, Strategic, and Statistical Considerations. Journal of Personality and Social Psychology, 51, 1173-1182.

https://doi.org/10.1037/0022-3514.51.6.1173

[36] McCabe, D. (2000) “Waiting for Dead Men's Shoes": Towards a cultural Understanding of Management Innovation. Human Relations, 55, 505-536. https://doi.org/10.1177/0018726702055005426

[37] Damanpour, F. (1996) Organizational Complexity and Innovation: Developing and Testing Multiple Contingency Models. Management Science, 42, 693-716. https://doi.org/10.1287/mnsc.42.5.693 